Article

\title{
The Value of Board Diversity in the Relationship of Corporate Governance and Investment Decisions of Pakistani Firms
}

\author{
Nauman Iqbal Mirza *, Qaisar Ali Malik ${ }^{(D)}$ and Ch Kamran Mahmood \\ Department of Business Administration, Foundation University, Islamabad 44000, Pakistan; \\ qamalik@gmail.com (Q.A.M.); arsalkamran@gmail.com (C.K.M.) \\ * Correspondence: naumaniqbal@gmail.com
}

Received: 8 October 2020; Accepted: 5 November 2020; Published: 13 November 2020

check for updates

\begin{abstract}
Inspired by the studies on the impact of diversity among decision-making groups, this study was carried out to examine whether the diversity of the members of the board of directors, encompassing gender, nationality, education, and experience, moderates the relationship between the corporate governance and investment decisions of listed companies of the Pakistan Stock Exchange. Furthermore, the determinants of investment decisions in the context of Pakistani firms' are also explored. Panel data analysis techniques are used to gauge the cause and effect relationship among the variables. We find short-term liquidity and profitability are the determinants of Pakistani firms' investment decisions, both having adverse relationships. Moreover, we explore board independence, and chief executive officer (CEO) duality has a significant positive impact on investment decisions. We further find that experience diversity strongly moderates the relationship between board independence and board size with investment decisions in the opposite direction. Education diversity moderates the relation of board size and investment decisions in the same direction. Foreign directors' presence on the board also significantly moderates the relationship between board independence and investment decisions. The results of this empirical study confirm that board diversity moderates the relationship between corporate governance and investment decisions.
\end{abstract}

Keywords: corporate governance; investment decisions; capital outlay decisions; capital budgeting; gender diversity; education diversity; experience diversity; nationality diversity and board diversity

\section{Introduction}

This research paper will emphasize the moderating impact of board diversity on the association between the firms' corporate governance and investment decisions. Since the beginning of the 21st century, growing diversity in demographics and cognition among the workforce in general and decision groups have been pressing issues. Because of regulators' emphasis, diversity in terms of gender has been explored mostly by the researchers regarding its impact on company performance. The financial management decisions taken by the members of a board of directors are aimed at maximizing shareholders' wealth. It necessitates exploring other dimensions of the board of directors' diversity, including gender, nationality, education, and experience. This research is, therefore, intended to gauge the moderating impact of diversity on decision making.

Corporate investment decisions are one of the financial management decisions made by the board of directors on behalf of the company's real owners, i.e., shareholders. These decisions may be undertaken for either investment or disinvestment [1,2]. The sole purpose of these decisions is to enhance the corporation's net wealth, ensuring an increase in the value of shares in the market. Subsequently, shareholders' wealth increases [3-5]. In the contemporary global era, it is urged that 
board diversity yields elevated decision-making, heightened vision, distinctive ideas, and creative marketing within diverse consumers [6-8]. Being the decision-making group, corporate boards are the focal point of firms' decisions [9]. Companies' operations' success is gauged by structure, caliber, and other corporate board's tactical characteristics comprising the directors. Therefore, the board's composition in terms of diversity is one of the significant issues being confronted globally by modern corporate stakeholders [10].

In large part, bifacial diversity can be contemplated within the team, encompassing perceptible diversity such as gender, ethnicity, age, etc., and imperceptible diversity such as education, exposure, etc. [11-13]. A comprehensive evaluation of available literature divulges that various attributes of the diversity of the board of directors are explored mostly in the context of firms' performance [14-21]. Furthermore, demographic diversity has been the primary focus of regulators as well as researchers, rather than cognitive diversity $[8,22-24]$.

Corporate governance, being the instrument available with shareholders to minimize agency costs, can influence the firms' investment decisions $[25,26]$. Therefore, it is imperative to study the moderating impact of board diversity on demography and cognition on the underlying relationship between corporate governance and firms' investment decisions. Furthermore, this paper also explores the determinants of investment decisions, especially in Pakistani firms.

Corporate governance is the utmost significant domain explored by researchers in Pakistan [3,27]. The corporate governance code was acquainted with the corporate world by the Security Exchange Commission of Pakistan (SECP) in 2002. It faced a lot of critique in Pakistan due to operational issues such as conflict of interest, focus on short-term results at the cost of long-term objectives, and enforcement issues such as the benchmark of corporate governance policies and procedures [28]. Yet, numerous researchers explored the topic of corporate governance in Pakistan.

Despite criticism and issues, SECP augmented corporate governance policies through development in phasis. SECP made it mandatory for boards to have at least one female director on reconstitution after expiring its current term under the Companies Act, 2017, to promote diversity. A survey report released by "Women on Board Pakistan" shows that only $11 \%$ of companies listed on the stock exchange represent women on board [29]. SECP does not emphasize other dimensions of board diversity beyond gender diversity. Furthermore, there is a lack of evidence concerning the moderating effect of board heterogeneity on the linkage between corporate governance and investment decisions. Hence, the gap in existing research needs to be filled, especially in developing economies like Pakistan.

Hence, conventional accounting factors affect the firm's investment decisions in addition to unconventional factors such as corporate governance. However, in the presence of the diversity of board members, characterized as gender, nationality, education, and experience, the relationship between corporate governance and firms' investment decisions may be affected. In response to the problem, this research aims to gauge the impact of moderation caused by the board of directors' diversity on the relationship between corporate governance and investment decisions. This study further intends to explore the relationship between cash flow from operations, leverage, profitability, and short-term liquidity on the firm's investment decisions, especially in Pakistan's context.

Penal data analysis is used for multivariate regression to explore the underlying model. Largely, researchers have used the fixed-effect model approach $[11,25,30,31]$, while few researchers who found a weak relationship among the variables in fixed/random effect models have used the generalized method of moments (GMM) to examine and overcome the issue of endogeneity with the penal data [32-34]. For this study, the employed model is the fixed effect model due to robust results.

The study results reveal that Pakistani firms having more short-term liquidity and profitability lead to a lack of investment. The study further elaborates that board independence and CEO duality affects the investment decisions of Pakistani firms. The results further support the idea that the board members' educational diversity negatively influences investment decisions in Pakistan's context. In contrast, experience diversity promotes corporate investments. The study's empirical results suggest a novel understanding that an independent board of directors of Pakistani firms, diverse in terms of 
experience, results in disinvestment. Boards with independent directors having nationality diversity also encourage corporate investments. The size of the board diverse in terms of experience negatively influences investment decisions. Corporate investments grow in the presence of a larger board size with education diversity. Furthermore, the boards that have the same individual as chairman and CEO of Pakistani firms with foreign national director's presence on the board also encourages investment.

This empirical study provides evidence that corporate governance significantly impacts the firms' investment decisions in Pakistani listed companies. The results further explore the accounting determinants of the corporate investment decisions of Pakistani companies. The most remarkable results of this study explore the moderating impact of board diversity encompassing education, experience, gender, and nationality on the relationship of corporate governance and investment decisions. The organization of the paper is as follows. This section gives a brief overview of the topic, economic context, and literature gaps. The analysis of available literature for hypothesis development is covered in the succeeding section. Section 3 describes the methodology of this research. The later section presents the analysis of the results. The final section of this paper describes conclusions and recommendations.

\section{Literature Review and Hypotheses Development}

\subsection{Investment Decisions}

From a corporate firms' perspective, an investment decision can be specified as a cash outlay on the company's resources to receive future cash inflows from these resources [2]. Investment decisions are generally the financial decisions relating to the long-term assets of the corporate firms. Therefore scarce resources have to be apportioned among contending opportunities through capital budgeting [27]. Efficient apportioning of capital to long-term assets to maximize the yield is one of the most vital financial roles of an organization $[28,35,36]$. Investment decisions are limited to apportioning funds to long-term assets. They encompass the utilization of funds, which are attained consequent to the assets' disposal, lacking profitability and productivity. It is beneficial to dispose of these assets, which do not contribute well [37]. The funds subsequently can be utilized to secure other productive assets.

Various researchers have attempted to find out the determinants of corporate investment decisions. Modigliani and Miller explain that the firms' investment decisions depend upon profitability, available cash flows, and firms' net worth [38]. Firms' accounting factors like cash flows, fixed asset concentration, and market-based measures like Tobin's q, firms' risk, and size are the major determinants of the firm's investment decisions [39]. Other authors postulate the previous levels of firms' investment, profitability, size, growth prospects, and cash flow as significant determinants of investment decisions [40].

However, researchers highlighted other determinants of investment decisions as already posited by [38]. Firms with higher leverage tend to lower capital assets as the higher the leverage, the higher the risk of bankruptcy. However, this adverse relationship intensifies, and Taiwanese firms have more growth opportunities [41]. One of the indicators of investment decisions is short-term liquidity. Profitability is lower when the firm's current ratio is higher because lower funds will be available to invest in the more profitable fixed assets [42]. Hence, conventional accounting factors influencing investment decisions include but are not limited to leverage, cash flows, return on assets, and short-term liquidity. Therefore, the hypotheses are as follows:

Hypothesis 1 (H1): Short term liquidity affects investment decisions.

Hypothesis 2 (H2): Leverage affects investment decisions.

Hypothesis 3 (H3): Return on assets affects investment decisions. 


\subsection{Corporate Governance}

In their seminal work, Berle and Means focus on the inevitable separation of ownership and control of modern corporate firms [43]. Owners of the firm include several investors, i.e., shareholders, also known as the principal. A large number of shareholders result in dispersed ownership of the company. On the other hand, executives control the firms' operations, also known as agents. The firm owners focus on the security of their investment and maximization of shareholding value.

On the other hand, the managers are pursuing their benefits such as job security, high remuneration, perks, privileges, etc. This parting of ownership and control leads to agency conflicts. The authors posit the idea of managerialism, in which the firm's goal is limited to preserving the shareholders' interest. Still, the other stakeholders' well-being must also be taken into account while making strategic decisions.

The goals being pursued by the managers, for their benefits in the principal-agent relationship, were emphasized by the agency theory. This situation arises from prioritizing the management's interest over the shareholders' interest [44]. The researchers challenged this traditional agency theory, leading toward the prediction of other theories such as stewardship theory and stakeholder theory $[25,36,45,46]$.

Corporate governance is a widely used tool to mitigate agency costs [47] and line up owners and management interests. This chore is executed by the firm's directors, customarily by authorization of decisions set forth by the firms' management and subsequent follow-up of the authorized decision execution. While performing the role of emissary of the shareholders, the board of directors ensures that corporate investment decisions are aligned with the firms' objective, i.e., value maximization and minimizing agency outlays. One such outlay is the investment in the assets maximizing the executives' own welfare at the expense of shareholders' wealth maximization. Conceptually and statistically, the investment decisions are affected by managerial welfare objectives. Its scope allows shareholders' welfare to affect investment decisions [48]. Executives make investment decisions concentrated on the firm's growth rather than profitability. Hence, most accessible internal funds are retained for investments rather than used for shareholder wealth maximization.

One of the integral attributes of corporate governance is board structure, evaluated by the total number of directors on the board, independent members, the proportion of the busy directors, board committees, etc. $[25,27]$. A significant impact of Brazilian firms' ownership and control structure on their investment decisions is found [49]. Brazilian firms possessed through pyramidal arrangements have less financial limitations. Still, the investment level of these firms is on the lower side. Over-investment in the maritime industry is related adversely to board size, corporate governance committees, and percentage of busy directors, while under-investment is positively related to governance committees [25]. Executive monitoring by independent directors can reduce the costs related to the agency. A significant direct relationship between capital and R \& D Investments with board independence exists [50]. The authors also analyze the impact of institutional shareholding on investment; however, they fail to maintain that agency costs can be reduced through shareholder activism. A significant direct relationship is found [51] between India's small business firms' board size and investment decisions.

On the contrary, an insignificant relationship between board size and board independence on the firms' $\mathrm{R} \& \mathrm{D}$ investment decisions is also found [52]. A researcher postulate that populous boards invest more in capital expenditures [53]. Simultaneously, other authors refuted the findings and explore a negative impact of board size on firms' investment.

Another corporate governance attribute is CEO duality, where the sole individual holds the Chairman and CEO's position. In such a scenario, the CEO may influence the board members. In the light of agency theory, the CEO dual role is undesirable, as board monitoring weakens with the grant of excess power to a single executive, resulting in lower firm performance [54,55]. Several researchers have studied the relationship between CEO duality and firm performance [25,56-58]; however, less empirical evidence is available to gauge the impact of CEO duality on corporate investment 
decisions. A significant positive impact of CEO duality on small firms' investment decisions in India through qualitative research is explored [51].

On the contrary, some researchers pose that firms that have a sole individual in the role of CEO and chairman make inefficient investments [55]. Other researchers also find the negative impact of CEO duality in a company on its investment performance [54]. In light of agency theory and carefully examining the available literature, hypotheses are below:

Hypothesis 4 (H4): There exists a relationship between board independence and investment decisions.

Hypothesis 5 (H5): There exists a relationship between board size and investment decisions.

Hypothesis 6 (H6): There exists a relationship between CEO duality and investment decisions.

\subsection{Diversity}

Researchers $[12,59,60]$ have largely categorized two extensive features of diversity, i.e., observable diversity such as age, gender, ethnicity, nationality, etc., and unobservable diversity such as expertise, education, experience, etc. Despite multiple dimensions of diversity, gender diversity has been a topic of most of the research studies [61-64].

Various theories are posed to elucidate the pros and cons of diversity's effects on firm performance. Cognitive diversity refers to team members' differences in characteristics such as experience, expertise, and perspectives. The cognitive diversity hypothesis advocates that underlying cognitive diversity features originating from cultural differences among group members tend toward newness, creative problem resolution, and improved team performance $[65,66]$. On the other hand, few researchers suggest that team heterogeneity has adverse implications on the decision-making in the light of theories such as social identity theory and similarity attraction paradigm. Social identity theory elaborates that group diversity may have negative outcomes due to the individuals' self-classification into social typecasts encompassing gender, age, ethnicity, etc. [67]. Likewise, the similarity attraction paradigm in contradiction to the cognitive diversity hypothesis shows that individuals are captivated by individuals with a similar mindset [68] and hence lack novelty in decision making.

The effective board of directors, being one of the pillars of a rich corporate governance context, plays a substantial part by opting for the new investment by not evaluating the anticipated investment solely in terms of viability. Still, firms compare cutoff rates of new investments vis-à-vis current investments to accommodate the allied risk. Increased gender diversity on the board of directors is detrimental to Swedish listed firms [54]. A few researchers [11], on the other hand, found no relationship between the board's diverseness regarding the relationship (i.e., gender, age, and race) with corporate investments. Women are perceived to have risk avoidance behavior, yet their presence on board reflected an insignificant relationship with the tendency to take the strategic risk [69].

The decision-making process is incomplete without experience [70]. Therefore, novelty can be achieved through experience-diverse teams while deciding against the given situation. Homogenous boards' effectiveness is lower when supervising investment-related activities than heterogeneous boards in terms of experience specific to the firm [11]. Hence, the chance of exploring new prospects with the presence of directors equipped with experience is higher because of the comprehension of directors' and board decisions' linkage. In terms of education, group diversity refers to the members' heterogeneity based on technological proficiency and perspectives [71]. Thus, the skillset and viewpoint of the individual with higher education shall differ from the contrary. Therefore, the board's diversity in education may result in newness of ideas and increased team efficiency. Another researcher [72] find a positive impact on gender and education diversity on corporate investment.

Foreign directors on the board represent board independence [9], contributing toward both governance and performance [18]. Diverseness of the board in terms of nationality promotes diverse viewpoints and cognition evolving through varied social backgrounds, expertise, and conception. 
As argued [9], the firms having foreign directors on their board directly relate to operating performance. The foreign directors are in minority slots and lack associations with the shareholders [18]. Some authors argued that their attendance record deteriorates with foreign national directors on the board, resulting in inferior performance [73]. On the contrary, a few researchers find no significant impact of nationality diversity on firm performance [74].

Consequent to the careful examination of the previous research, it is inferred that although rational, diversity leads to moderated decisions [70,71], however empirical evidence for the presence of moderating role of diversity while making financial management decisions by the board is yet to be explored. Our inference that a heterogeneous board of directors in term of gender, education, experience, and nationality moderate the relationship between corporate governance and investment decisions of the firm corresponds to the inference of the researchers, who study and find compelling evidence of the moderating role of board diversity on the association between corporate governance and firm performance [75]. The possible association of financial management decisions related to investment with the corporate governance practices through a board of directors diverse in terms of gender, education, nationality and experience, and conventional accounting factors must be explored. In the light of cognitive diversity hypotheses, the following is inferred to test the direct and moderating effect of board diversity in terms of gender, education, experience, and nationality:

Hypothesis 7 (H7): Board diversity is significantly related to investment decisions.

Hypothesis 8 (H8): Board diversity significantly moderates the relationship between board independence and investment decisions.

Hypothesis 9 (H9): Board diversity significantly moderates the relationship between board size and investment decisions.

Hypothesis 10 (H10): Board diversity significantly moderates the relationship between CEO duality and investment decisions.

\section{Research Methodology}

\subsection{Variables of Study}

General-to-specific modeling is used to explore the underlying optimal model for this study. Empirical investigation originates with a generalized statistical model that scales the vital attributes of the underlying dataset. Consequent to the step-wise eradication of the insignificant variables, the generalized statistical model's complexity is tweaked while ensuring the optimum model's consistency [75].

The optimized model for this research is achieved by exploring the effect of corporate governance (CEO duality, the board size, and board independence) and conventional accounting variables (cash flows from operations, short term liquidity, financial leverage, and return on assets) as independent variables on investment decisions as a dependent variable. Board diversity attributes, i.e., gender, education, experience, and nationality, were considered moderating variables. Measurement of variables is shown in Table 1. 
Table 1. Measurement of Variables.

\begin{tabular}{cc}
\hline \multicolumn{1}{c}{ Variables } & Measurement \\
\hline Short term liquidity (SL) & The ratio of current assets to current liabilities [42] \\
\hline Financial leverage (LEV) & The ratio of debt to assets [39] \\
\hline Return on assets (ROA) & EAT to total assets [76] \\
\hline Board Independence (BI) & Log (Number of independence directors) [27] \\
\hline Board size (BS) & Log (Number of directors) [76] \\
\hline CEO duality (CEOD) & One if chairman \& CEO of the firm is one person, otherwise zero [76] \\
\hline Experience diversity (XD) & Average education of the directors of the firm [68] \\
\hline Education diversity (ED) & The ratio of female director to total directors on the board [78] \\
\hline Gender diversity (GD) & The ratio of foreign director to total directors on the board [74] \\
\hline Nationality diversity (ND) & Rate of net fixed assets to total assets [79]) \\
\hline Investment decisions (ID) &
\end{tabular}

\subsection{Population and Sample}

The study is conducted on the listed non-financial companies of the Pakistan Stock Exchange (PSX). The data pertains to the publicly listed companies (PLCs) spread over eight years (2010 to 2017). Due to the lack of a declaration of data about board diversity by most companies, the sample was selected of 175 companies. The sampling method, thus adopted for this study, is the "convenience sampling method" under non-probability sampling techniques. We collected the financial data from the annual accounts of the companies. Data about diversity was collected from various sources, including annual reports of the companies and directors' profiles on websites/social media networks (www.linkedin.com, www.bloomberg.com). There are 36 overall sectors of Pakistan listed companies. For this research, the selected observations encompass 25 sectors of the manufacturing and service industry. Table 2 summarizes the industrial sector of the sample firms.

Table 2. Industrial Sectors of Sample Firms.

\begin{tabular}{lc}
\hline Industrial Sectors & No of obs. \\
\hline Textile Spinning & 30 \\
Textile Composite & 19 \\
Chemical & 16 \\
Sugar \& Allied Industries & 15 \\
Cement & 13 \\
Engineering & 10 \\
Automobile Assembler & 10 \\
Power Generation \& Distribution & 9 \\
Food \& Personal Care Products & 9 \\
Automobile Parts \& Accessories & 5 \\
Pharmaceuticals & 4 \\
Glass \& Ceramics & 4 \\
Paper \& Board & 4 \\
Fertilizer & 4 \\
Miscellaneous & 23 \\
\hline
\end{tabular}

\subsection{Econometric Models}

The direct relationship between corporate governance, conventional accounting variables (determinants), diversity, and investment decisions were estimated through step-wise regression using models 3.3.1 to 3.3.3. Simultaneously, the interacting effects of diversity on the relation between corporate governance and investment decisions were estimated by using model 3.3.4. 
Model 3.3.1.

$$
\mathrm{ID}_{\mathrm{it}}=\beta_{0}+\beta_{1} \mathrm{BI}_{\mathrm{it}}+\beta_{2} \mathrm{BS}_{\mathrm{it}}+\beta_{3} \mathrm{CEOD}_{\mathrm{it}}+\epsilon_{\mathrm{it}}
$$

Model 3.3.2.

$$
\mathrm{ID}_{\mathrm{it}}=\beta_{0}+\beta_{1} \mathrm{BI}_{\mathrm{it}}+\beta_{2} \mathrm{BS}_{\mathrm{it}}+\beta_{3} \mathrm{CEOD}_{\mathrm{it}}+\beta_{4} \mathrm{SL}_{\mathrm{it}}+\beta_{5} \mathrm{LEV}_{\mathrm{it}}+\beta_{6} \mathrm{ROA}_{\mathrm{it}}+\epsilon_{\mathrm{it}}
$$

Model 3.3.3.

$$
\begin{aligned}
\mathrm{ID}_{\text {it }}=\beta_{0}+\beta_{1} \mathrm{BI}_{\text {it }} & +\beta_{2} \mathrm{BS}_{\text {it }}+\beta_{3} \mathrm{CEOD}_{\text {it }}+\beta_{4} \mathrm{SL}_{\text {it }}+\beta_{5} \mathrm{LEV}_{\mathrm{it}}+\beta_{6} \mathrm{ROA}_{\mathrm{it}}+\beta_{7} \mathrm{XD}_{\mathrm{it}} \\
& +\beta_{8} \mathrm{ED}_{\mathrm{it}}+\beta_{9} \mathrm{GD}_{\mathrm{it}}+\beta_{10} \mathrm{ND}_{\text {it }}+\epsilon_{\text {it }}
\end{aligned}
$$

Model 3.3.4.

$$
\begin{aligned}
& \mathrm{ID}_{\text {it }}=\beta_{0}+\beta_{1} \mathrm{BI}_{\mathrm{it}}+\beta_{2} \mathrm{BS}_{\mathrm{it}}+\beta_{3} \mathrm{CEOD}_{\mathrm{it}}+\beta_{4} \mathrm{SL}_{\mathrm{it}}+\beta_{5} \mathrm{LEV}_{\mathrm{it}}+\beta_{6} \mathrm{ROA}_{\mathrm{it}}+\beta_{7} \mathrm{XD}_{\mathrm{it}} \\
& +\beta_{8} \mathrm{ED}_{\mathrm{it}}+\beta_{9} \mathrm{GD}_{\mathrm{it}}+\beta_{10} \mathrm{ND}_{\mathrm{it}}+\beta_{11} \mathrm{BI} * \mathrm{XD_{it }}+\beta_{12} \mathrm{BS} * \mathrm{X} \mathrm{D}_{\mathrm{it}} \\
& +\beta_{13} \mathrm{CEOD} * \mathrm{X} \mathrm{D}_{\mathrm{it}}+\beta_{14} \mathrm{BI} * \mathrm{ED} \text { it }+\beta_{15} \mathrm{BS} * \mathrm{ED}_{\mathrm{it}}+\beta_{16} \mathrm{CEOD} * \mathrm{ED} \text { it } \\
& +\beta_{17} \mathrm{BI} * \mathrm{GD}_{\mathrm{it}}+\beta_{18} \mathrm{BS} * \mathrm{GD}_{\mathrm{it}}+\beta_{19} \mathrm{CEOD} * \mathrm{GD}_{\mathrm{it}}+\beta_{20} \mathrm{BI} * \mathrm{ND} \text { it } \\
& +\beta_{21} \mathrm{BS} * \mathrm{ND} D_{\mathrm{it}}+\beta_{22} \mathrm{CEOD} * \mathrm{ND}_{\mathrm{it}}+\epsilon_{\mathrm{it}}
\end{aligned}
$$

\subsection{Econometric Methodology}

Generally, estimation methods used for panel data analysis are the ordinary least squared, fixed-effects model, and random effects model [40]. Mostly, the researchers assume that the invisible individual effect is nil and pooled the ordinary least squared regression to estimate the investment equations 3.3.1 and 3.3.2. This assumption leads to the problem of heterogeneity across industries and firms within the same industries. Hence, FEM and REM are used to cope with this problem.

\section{Results and Discussion}

\section{Diagnostic Tests}

Table 3 below presents the summary statistics for the variables used in explaining the model:

Table 3. Descriptive Statistics (Sample Size $=175, \mathrm{~N}=1225$ ). Panel A.

\begin{tabular}{ccccccc}
\hline Var. & Obs. & Mean & SD & Min & Max & Median \\
\hline ID & 1225 & 0.734 & 0.592 & 0.000 & 0.873 & 0.690 \\
BI & 1225 & 0.153 & 0.138 & 0.000 & 1.000 & 0.143 \\
BS & 1225 & 2.043 & 0.225 & 1.945 & 2.773 & 1.946 \\
CEOD & 1225 & 0.141 & 0.348 & 0.000 & 1.000 & 0.000 \\
SL & 1225 & 2.470 & 12.707 & 0.000 & 316.832 & 1.151 \\
LEV & 1225 & 0.243 & 4.986 & -115.828 & 61.427 & 0.177 \\
ROA & 1225 & 0.039 & 0.159 & -2.643 & 1.751 & 0.037 \\
XD & 1225 & 3.475 & 0.612 & 0.000 & 4.087 & 3.584 \\
ED & 1225 & 2.660 & 0.540 & 2.302 & 3.073 & 2.773 \\
GD & 1225 & 0.086 & 0.133 & 0.000 & 0.571 & 0.000 \\
ND & 1225 & 0.046 & 0.120 & 0.000 & 0.857 & 0.000 \\
\hline
\end{tabular}

The mean value of ID is 0.73 , with the least value of zero and an extreme value of 0.87 , signaling that the rate of net fixed assets to Pakistani firms' total assets is $73 \%$. As far as corporate governance is concerned, PLCs' average board independence is 0.15 or $15 \%$ of the total board size, with a standard deviation of 0.14 . On the other hand, the mean board size is 2.04 (8 members), with the least value of 1.95 ( 7 members) and an extreme value of 2.77 (16 members). The descriptive statistics of CEOD, i.e., a single person as chairman and CEO, show an average value of 0.14 . Further analysis of the data reveals that out of 1225 observations, there are only 173 instances where CEOD exists. 
Descriptive statistics related to determinants of investment decisions show that the mean SL value is 2.270 . The top value is 316.83 , while the bottom value is zero. The statistics show that the ratio of current assets to current liabilities of Pakistani firms is almost double. Statistics on LEV show that Pakistani firms finance $24 \%$ of the total assets with debt on average. In terms of profitability, the mean value of ROA is 0.39 , with a standard deviation of 0.159 .

While exploring the descriptive statistics of diversity variables, interesting results are observed. The mean value of XD (experience of members of the board of directors) is 3.48 (32 years), with a minimum value of zero and a maximum value of 4.08 (59 years). Panel B explores experience diversity observations, revealing that $56 \%$ of the total observations of the board's average experience are between 30 to 40 years, $18 \%$ of the observations have average experience less than 30 years, and $26 \%$ of the total observations have more than 40 years.

Panel B.

\begin{tabular}{ccc}
\hline Experience in Years & Observations & Percentage \\
\hline Less than 30 years & 222 & $18 \%$ \\
Between 30 to 40 years & 692 & $56 \%$ \\
More than 40 years & 311 & $26 \%$ \\
\hline
\end{tabular}

On the other hand, the ED of Pakistani firms that has an average of 2.66 is 14 years (i.e., average education of the board of directors is graduate). Maximum education is 3.07 (21 years). Panel C shows that out of 1225 observations, 955 have education years between 14 to $16.5 \%$ of the observations have education less than 14 years, while $17 \%$ of the observations have more than 16 years of education.

Panel C

\begin{tabular}{ccc}
\hline Years of Education & Observations & Percentage \\
\hline 12 to 14 years of education & 59 & $5 \%$ \\
14 to 16 years of education & 955 & $78 \%$ \\
$\begin{array}{c}\text { More than 16 years of } \\
\text { education }\end{array}$ & 211 & $17 \%$ \\
\hline
\end{tabular}

Descriptive statistics of GD show that $8 \%$ of the total members of the board of directors are female on average. While GD maximum value is 0.57 , i.e., $57 \%$ of female directors are on the board for PLCs at maximum. Further discovering the GD data, only $38 \%$ of total observations have one or more female directors on the board. Panel D expresses that 237 observations out of 1225 observations have only one female director, 128 have two directors, and 102 have three or more female directors on board.

Panel D

\begin{tabular}{ccc}
\hline Number of Female Directors on Board & Observations & Percentage \\
\hline None & 757 & $62 \%$ \\
One & 237 & $19 \%$ \\
Two & 129 & $11 \%$ \\
Three or more & 102 & $8 \%$ \\
\hline
\end{tabular}

Finally, the average value of ND is 0.046 , with a standard deviation of 0.12 , with a minimum value of zero and a maximum value of 0.86 . It shows that $5 \%$ of board members are foreign nationals. Panel E depicts that $19 \%$ of the total observations have diverse boards in terms of nationality. One hundred twelve boards have one foreign national director, fifty-six boards have two, and fifty-nine boards have three or more foreign national directors. 
Panel E

\begin{tabular}{ccc}
\hline Number of Foreign Directors & Observations & Percentage \\
\hline None & 998 & $81 \%$ \\
One & 112 & $9 \%$ \\
Two & 56 & $5 \%$ \\
Three or More & 59 & $5 \%$ \\
\hline
\end{tabular}

Results of the correlation matrix of the independent variables are appended in Table 4.

Table 4. Correlation Matrix (Sample Size $=175, \mathrm{~N}=1225$ ).

\begin{tabular}{|c|c|c|c|c|c|c|c|c|c|c|}
\hline & Var & BI & BS & CEOD & SL & LEV & ROA & XD & ED & GD \\
\hline 1 & $\mathrm{BI}$ & 1.000 & & & & & & & & \\
\hline 2 & BS & 0.035 & 1.000 & & & & & & & \\
\hline 3 & CEOD & -0.136 & -0.113 & 1.000 & & & & & & \\
\hline 4 & SL & 0.021 & -0.013 & -0.029 & 1.000 & & & & & \\
\hline 5 & LEV & 0.008 & -0.024 & 0.020 & -0.004 & 1.000 & & & & \\
\hline 6 & ROA & 0.058 & 0.118 & -0.078 & 0.012 & 0.037 & 1.000 & & & \\
\hline 7 & XD & -0.032 & 0.282 & 0.034 & 0.020 & -0.018 & 0.028 & 1.000 & & \\
\hline 8 & ED & -0.013 & 0.275 & 0.057 & 0.023 & -0.013 & 0.033 & $0.759 *$ & 1.000 & \\
\hline 9 & GD & 0.034 & 0.028 & -0.040 & 0.107 & -0.009 & -0.011 & -0.016 & 0.064 & 1.000 \\
\hline 10 & ND & 0.045 & -0.008 & -0.042 & 0.042 & -0.014 & 0.043 & 0.038 & 0.096 & -0.171 \\
\hline
\end{tabular}

Table 4 illustrates the correlation between the independent variables. The relationship among the regressors is weak, signifying the absence of multi-collinearity. The results of central values of variance inflation factor (VIF) of the regressors are well within the tolerance limit, i.e., below 5 , also validate that inference.

The panel data analysis is used to test the hypotheses in equations of model 3.3.1 and 3.3.2. The fixed-effect redundancy test is used to decide the appropriate model between common effect and random effect, wherein F Stats is found significant with a $p$-value of less than 0.05 . Subsequently, the Hausman Test is used to select the relevant model between the fixed and random effect model, depicting H-Stats' $p$-value of less than 0.05. Hence, the fixed-effect model is used to explain the relationship between the variables.

Table 5 shows the results of testing of hypothesis with the equations in model 3.3.1 to 3.3.4. The impact of CG on ID shows that BI (Coeff $=0.254$ ) has a significant positive impact at a $10 \%$ confidence interval, which is in line with the earlier studies $[50,80]$ as well as with agency theory. The results show the compliance of the Code of Corporate Governance by Pakistani listed firms. Hence, $\mathrm{H} 4$ is accepted. BS (Coeff $=-0.037$ ) has an insignificant impact on the ID. This insignificant relation may be attributed to the stagnant average board size of Pakistani firms, i.e., eight members. Based on the results, $\mathrm{H} 5$ is rejected. CEOD (Coeff $=0.105$ ), on the contrary, have a strong direct relationship with ID. CEOD advocates tight contact among the board with added malleability; therefore, the results suggest the acceptance of $\mathrm{H} 6$.

The results of model 3.3.2 show that SL has a significant negative impact (Coeff $=-0.0552)$ on investment decisions. This adverse relation is because an increase in short-term liquidity is at the cost of long-term investments [42]. Likewise, ROA (Coeff $=-0.339)$ has a strong negative impact on investment decisions. The results confirm our hypotheses H3. With an increase in capital investment, profitability tends to decrease. Levered firms (Coeff $=-0.003$ ) negatively impact ID. However, the relationship is insignificant. Results relating to corporate governance variables are in line with model 3.3.1. 
Table 5. Impact of conventional accounting variables, corporate governance, and board diversity on investment decisions (Sample Size $=175, \mathrm{~N}=1225$ ).

\begin{tabular}{|c|c|c|c|c|c|c|c|c|c|}
\hline \multirow[t]{2}{*}{ Variable } & \multirow[t]{2}{*}{ Sign } & \multicolumn{2}{|c|}{ Model 3.3.1 CG } & \multicolumn{2}{|c|}{ Model 3.3.2 DET } & \multicolumn{2}{|c|}{ Model 3.3.3 DIV } & \multicolumn{2}{|c|}{$\begin{array}{l}\text { Model 3.3.4 DIV with } \\
\text { Interaction Terms }\end{array}$} \\
\hline & & Coeff & $p$-Value & Coeff & $p$-Value & Coeff & $p$-Value & Coeff & $p$-Value \\
\hline $\mathrm{BI}$ & + & 0.254 & $0.065 *$ & 0.291 & $0.031^{* *}$ & 0.257 & $0.059 *$ & 1.147 & $0.080 *$ \\
\hline BS & - & -0.037 & 0.777 & -0.038 & 0.766 & -0.051 & 0.703 & -0.004 & 0.980 \\
\hline CEOD & $+/-$ & 0.105 & $0.023^{* *}$ & 0.101 & $0.025^{* *}$ & 0.104 & 0.022 ** & 0.121 & $0.021^{* *}$ \\
\hline SL & - & & & -0.006 & $0.000 * * *$ & -0.006 & $0.000^{* * *}$ & -0.006 & $0.000^{* * *}$ \\
\hline LEV & - & & & -0.003 & 0.295 & -0.002 & 0.301 & -0.002 & 0.304 \\
\hline ROA & - & & & -0.339 & $0.000 * * *$ & -0.343 & $0.000^{* * *}$ & -0.342 & $0.000^{* * *}$ \\
\hline $\mathrm{XD}$ & + & & & & & 0.197 & $0.101 *$ & 1.725 & $0.011 * *$ \\
\hline ED & $+/-$ & & & & & -0.252 & 0.127 & -2.171 & $0.014^{* *}$ \\
\hline GD & - & & & & & 0.005 & 0.806 & 0.018 & 0.520 \\
\hline ND & + & & & & & 0.007 & 0.794 & 0.016 & 0.615 \\
\hline $\mathrm{BI} \times \mathrm{XD}$ & & & & & & & & -0.239 & $0.097^{*}$ \\
\hline $\mathrm{BS} \times \mathrm{XD}$ & & & & & & & & -0.736 & $0.025^{* *}$ \\
\hline $\mathrm{BS} \times \mathrm{ED}$ & & & & & & & & 0.951 & $0.025^{* *}$ \\
\hline $\mathrm{BI} \times \mathrm{GD}$ & & & & & & & & -0.067 & 0.536 \\
\hline $\mathrm{CEOD} \times \mathrm{GD}$ & & & & & & & & -0.034 & 0.491 \\
\hline $\mathrm{BI} \times \mathrm{ND}$ & & & & & & & & 0.060 & $0.059^{* *}$ \\
\hline $\mathrm{C}$ & & 0.757 & $0.005^{* * * *}$ & 0.784 & $0.003^{* * *}$ & 0.795 & $0.005^{* * *}$ & 0.536 & 0.223 \\
\hline Obs. & & \multicolumn{2}{|c|}{1225} & \multicolumn{2}{|c|}{1225} & \multicolumn{2}{|c|}{1225} & \multicolumn{2}{|c|}{1225} \\
\hline F-stats (prob.) & & \multicolumn{2}{|c|}{$0.000^{* * *}$} & \multicolumn{2}{|c|}{$0.000 * * *$} & \multicolumn{2}{|c|}{$0.000 * * *$} & \multicolumn{2}{|c|}{$0.000 * * *$} \\
\hline Adj R-sqrd & & \multicolumn{2}{|c|}{0.522} & \multicolumn{2}{|c|}{0.542} & \multicolumn{2}{|c|}{0.542} & \multicolumn{2}{|c|}{0.542} \\
\hline
\end{tabular}

Results of mode 3.3.3 include all of the independent variables, i.e., corporate governance, determinants, and diversity. Experience diversity XD $($ Coeff $=0.197)$ showed a positive relationship with ID, which is in concurrence with cognitive diversity hypotheses, i.e., diverse boards in term of experience leads to innovation, thus leading to more investments [11,66,70]. No strong relationship is found with other diversity variables, i.e., ED, GD, and ND on ID. However, based on the relationship of $\mathrm{XD}$ and ID, H7 is accepted. BI, CEOD, SL, and ROA have shown similar results as prior models.

Finally, Model 3.3.4 exhibits the relationship between corporate governance, accounting variables, and diversity on investment decisions. In this model, diversity variables are used as an interaction term with the proxies of corporate governance to gauge the moderating impact of diversity on investment decisions. The impact of corporate governance and investment decisions conform with the results of preceding models. BI (Coeff $=1.147)$ and CEOD $($ Coeff $=0.121)$ have strong positive impacts on ID. Similarly, SL (Coeff $=-0.006)$ and ROA $(-0.342)$ adversely influence the ID, and the relation is highly significant. $\mathrm{XD}$ (Coeff $=1.725)$ is also in accord with the results of model 4.3.3. ED (Coeff $=$ -2.171 ), on the contrary, has a significant negative impact on ID. The similarity attraction paradigm highlights that increased heterogeneity tends to captivate individuals with a similar mindset lacking new decision-making. Thus, $\mathrm{H} 7$ is accepted.

$\mathrm{BI}$ with a heterogeneous board based on $\mathrm{XD}(\mathrm{BI} \times \mathrm{XD}$, Coeff $=-0.239)$ negatively influences the Pakistani firms' ID. Although the diverse boards are more independent [10], in contrast to the agency theory BI of the sample companies adversely impact ID. The rationale behind this adverse impact increase in diversity may be that it leads to self-isolation, lack of coordination, and poor decision-making. Harmoniously, BS with a diverse board in terms of experience $(B S \times X D$, Coeff $=$ $-0.736)$ also affects ID adversely. Cognitive diversity hypotheses suggest that cognitively diverse boards improve decision making. However, the outcome of the model shows contrary results.

The moderating impact of BS with ED (Coeff $=0.951$ ) shows a strong positive impact on the ID. The results are in harmony with cognitive diversity hypotheses, which describe that larger 
heterogeneous teams in terms of cognition result in innovation and improved decision-making. ND moderates the linkage of BI (Coeff $=0.060)$ and ID in the same direction. Again, the results are congruent with the cognitive diversity hypotheses. The moderating role of diversity with other forms of corporate governance is not observed. Given the significant results, hypotheses H8 and H9 are accepted, and $\mathrm{H} 10$ is rejected.

Collectively, the above results suggest that the heterogeneous board of directors contributes to the firms' investment decisions and tends to moderate corporate governance's impact on investment decisions.

\section{Conclusions and Recommendations}

This study focuses on the relationship between the firms' corporate governance and investment decisions in the light of agency theory and the impact of conventional accounting variables as determinants of investment decisions. The findings on the moderating role of board diversity on the relationship between corporate governance and investment decisions are among this study's emphases. The dataset used is from 2010 to 2017 and includes 175 listed non-financial companies of PSX. Our work has led us to conclude that an adverse relationship between the orthodox factors (Short-Term Liquidity and Profitability) and corporate investment decisions exists. The evidence from this study further suggests that board independence positively influences Pakistani firms' investment decisions consistent with the agency theory. In contrast with the agency theory, CEO duality shows a positive impact on PLCs' investment decisions.

This study's finding further supports the idea that the board members' experience diversity positively influences investment decisions, while education diversity impacts them negatively. The effect of experience diversity on decision making is in line with the cognitive diversity hypotheses. This study's empirical findings offer a novel understanding of the moderating role of experience and education and nationality diversity on the linkage between investment decisions and corporate governance. We have managed to find the moderating impact of diversity (experience, education, and nationality) on the relationship between corporate governance (board independence and board size) and investment decisions. These findings collectively suggest that a heterogeneous board of directors moderates the relationship between corporate governance and investment decisions. The major limitation is the small sample size due to the scarcity of data about the diversity of directors' diversity due to the lack of declaration of most of the PLCs.

The results thus clearly show that corporate governance practices impact the investment decisions of Pakistani firms. The results further shed light on the determinants of investment decisions in the context of Pakistani markets. This empirical results of this research contribute to the existing literature by identifying the moderating role of board diversity on the relationship between corporate governance and investment decisions.

The outcomes of this research unfold significant evidence for top management, planners, policymakers, investors, and future researchers as well. This study guides investors to invest in firms with heterogeneous board members regarding experience and nationalism to lessen agency costs. This study provides guidelines to the policymakers, i.e., Securities and Exchange Commission of Pakistan, to elaborate policies encouraging the diversity of board members to foster improved decisions with a better understanding of the problems and uniqueness of ideas. Besides, the policymakers shall make guidelines to ensure mandatory disclosure of information related to board members' characteristics by the listed companies in the annual reports and before the directors' election, to have better insight into the board's diversity by the investors and other stakeholders. We are confident that our research will serve as a base for future studies by adding other facets of corporate governance practices such as block shareholders, percentage of insider shareholding, institutional shareholding, and presence and quality of corporate governance committees. Future researchers may also explore other dimensions of financial management decisions. 
Author Contributions: All authors have read and agree to the published version of the manuscript. All authors contributed to conceptualization, methodology, validation, formal analysis, investigation, resources, data curation of the paper. The original draft is prepared and written by N.I.M. Reviewing and editing is made by C.K.M. Supervision is done by Q.A.M. EViews software is used for data analysis.

Funding: No financial support is received for this publication.

Conflicts of Interest: The authors declare no conflict of interest.

\section{References}

1. Kang, S.H.; Kumar, P.; Lee, H. Agency and corporate investment: The role of executive compensation and corporate governance. J. Bus. 2006, 79, 1127-1147. [CrossRef]

2. Pogue, M. Corporate Investment Decisions: Principles and Practice. In Corporate Investment Decisions: Principles and Practice; Business Expert Press, LLC: New York, NY, USA, 2010. [CrossRef]

3. Akbar, M.; Hussain, S.; Ahmad, T.; Hassan, S. Corporate governance and firm performance in Pakistan: Dynamic panel estimation. Abasyn J. Soc. Sci. 2019, 12, 213-230. [CrossRef]

4. Bainbridge, S.M. Why a board? Group decision making in corporate governance. Vanderbilt Law Rev. 2002, 55, 1-55. [CrossRef]

5. Kang, H.; Cheng, M.; Gray, S.J. Corporate governance and board composition: Diversity and independence of Australian boards. Corp. Gov. An Int. Rev. 2007, 15, 194-207. [CrossRef]

6. Cox, T. The Multicultural Organization. Acad. Manag. Exec. 1991, 5, 34-47. [CrossRef]

7. Ekaningtias, D. The effect of diversity of the nationality, board of director, investment decision, financing decision, and dividend policy to company values. Theor. Appl. Sci. 2018, 65, 82-91. [CrossRef]

8. Kagzi, M.; Guha, M. Does board demographic diversity influence firm performance? Evidence from Indian-knowledge intensive firms. Benchmarking 2018, 25, 1028-1058. [CrossRef]

9. Estélyi, K.S.; Nisar, T.M. Diverse boards: Why do firms get foreign nationals on their boards? J. Corp. Financ. 2016, 39, 174-192. [CrossRef]

10. Simpson, W.G.; Carter, D.A.; D'Souza, F. What Do We Know About Women on Boards? J. Appl. Financ. 2010, $20,27$.

11. Harjoto, M.A.; Laksmana, I.; Yang, Y. Board diversity and corporate investment oversight. J. Bus. Res. 2018, 90, 40-47. [CrossRef]

12. Milliken, F.J.; Martins, L.L. Searching for common threads: Understanding the multiple effects of diversity in organizational groups. Acad. Manag. Rev. 1996, 21, 402-433. [CrossRef]

13. Torchia, M.; Calabro, A.; Morner, M. Board of directors' diversity, creativity, and cognitive conflict. Int. Stud. Manag. Organ. 2015, 45, 6-24. [CrossRef]

14. Ali, M.; Ng, Y.L.; Kulik, C.T. Board Age and Gender Diversity: A Test of Competing Linear and Curvilinear Predictions. J. Bus. Ethics 2013, 125, 497-512. [CrossRef]

15. Bear, S.; Rahman, N.; Post, C. The impact of board diversity and gender composition on corporate social responsibility and firm reputation. J. Bus. Ethics 2010, 97, 207-221. [CrossRef]

16. Dobbin, F.; Jung, J. Corporate Board Gender Diversity and Stock Performance: The Competence GAP or Institutional Investor Bias? North Carol. Law Rev. 2011, 89, 809-838. [CrossRef]

17. Pruitt, S.W.; Gitman, L.J. The Interactions between the Investment, Financing, and Dividend Decisions of Major U.S. Firms. Financ. Rev. 1991, 26, 409-430. [CrossRef]

18. Ruigrok, W.; Peck, S.; Tacheva, S. Nationality and gender diversity on Swiss corporate boards. Corp. Gov. Int. Rev. 2007, 15, 546-557. [CrossRef]

19. Seierstad, C.; Gabaldon, P.; Mensi-Klarbach, H. Gender Diversity in the Boardroom; Palgrave Macmillan: London, UK, 2017; Volume 2. [CrossRef]

20. Van Veen, K.; Elbertsen, J. Governance regimes and nationality diversity in corporate boards: A comparative study of Germany, the Netherlands and the United Kingdom. Corp. Gov. An Int. Rev. 2008, 16, 386-399. [CrossRef]

21. Wang, Y.; Clift, B. Is there a "business case" for board diversity? Pac. Account. Rev. 2009, 21, 88-103. [CrossRef]

22. Ararat, M.; Aksu, M.; Tansel Cetin, A. How board diversity affects firm performance in emerging markets: Evidence on channels in controlled firms. Corp. Gov. An Int. Rev. 2015, 23, 83-103. [CrossRef] 
23. Buse, K.; Bernstein, R.S.; Bilimoria, D. The Influence of Board Diversity, Board Diversity Policies and Practices, and Board Inclusion Behaviors on Nonprofit Governance Practices. J. Bus. Ethics 2016, 133, 179-191. [CrossRef]

24. Miller, T.; Del Carmen Triana, M. Demographic diversity in the boardroom: Mediators of the board diversity-firm performance relationship. J. Manag. Stud. 2009, 46, 755-786. [CrossRef]

25. Andreou, P.C.; Louca, C.; Panayides, P.M. Corporate governance, financial management decisions and firm performance: Evidence from the maritime industry. Transp. Res. Part E Logist. Transp. Rev. 2014, 63, 59-78. [CrossRef]

26. Mueller, D.C.; Peev, E. Corporate Governance and Investment in Central and Eastern Europe. J. Comp. Econ. 2007, 35, 414-437. [CrossRef]

27. Waheed, A.; Malik, Q.A. Board characteristics, ownership concentration and firms' performance: A contingent theoretical based approach. South Asian J. Bus. Stud. 2019, 8, 146-165. [CrossRef]

28. Javid, A.Y.; Iqbal, R. Corporate governance in Pakistan: Corporate valuation, ownership and financing. Work. Pap. Res. Rep. 2010, 2010.

29. Haq, S. Gender Inequality in Pakistan. Available online: https://ribune.com. pk/story/2174274/2-gender-inequality-pakistan-11-listed-firms-female-director/?fbclid= IwAR2BBNfwN8tWcVmn45aZPnmUIIHQtdGO5z-dQrcsdpGQDaOK3TwGy8nPU7Q (accessed on 20 March 2020).

30. Fazzari, S.M.; Hubbard, R.G.; Petersen, B.C.; Blinder, A.S.; Poterba, J.M. Financing Constraints and Corporate Investment. Brook. Pap. Econ. Act. 1988, 1988, 141. [CrossRef]

31. Sarhan, A.A.; Ntim, C.G.; Al-Najjar, B. Board diversity, corporate governance, corporate performance, and executive pay. Int. J. Financ. Econ. 2019, 24, 761-786. [CrossRef]

32. Bennouri, M.; Chtioui, T.; Nagati, H.; Nekhili, M. Female board directorship and firm performance: What really matters? J. Bank. Financ. 2018, 88, 267-291. [CrossRef]

33. Byoun, S.; Chang, K.; Kim, Y.S. Does Corporate Board Diversity Affect Corporate Payout Policy? Asia-Pac. J. Financ. Stud. 2011, 45, 48-101. [CrossRef]

34. Khan, I.; Khan, I.; Saeed, B. Does board diversity affect quality of corporate social responsibility disclosure? Evidence from Pakistan. Corp. Soc. Responsib. Environ. Manag. 2019, 26, 1371-1381. [CrossRef]

35. Matiin, N.; Ratnawati, T.; Riyadi, S. The Influence of Investment Decisions, Funding Decisions, Risk of Strategy, To Efficeincy, Finance Performance, Value of Firm, Good Corporate Governance As Moderating Variable In The Mining Company Coal Sub Sector Go Public In Indonesia Stock Exchange. Arch. Bus. Res. 2018, 6, 374-383. [CrossRef]

36. Shahid, M.S.; Abbas, M. Does corporate governance play any role in investor confidence, corporate investment decisions relationship? Evidence from Pakistan and India. J. Econ. Bus. 2019, 105, 105839. [CrossRef]

37. Sachdev, J.C. Disinvestment: A Corporate Failure or a Strategic Success. Int. Stud. Manag. Organ. 1976, 6, 112-130. [CrossRef]

38. Modigliani, F.; Miller, M.H. The Cost of Capital, Corporation Finance and the Theory of Investment. Am. Econ. Rev. 1958, 48, 261-297. [CrossRef]

39. Nguyen, P.D.; Dong, P.T.A. Determinants of Corporate Investment Decisions: The Case of Vietnam. J. Econ. Dev. 2013, 32, 32-48. [CrossRef]

40. Bokpin, G.A.; Onumah, J.M. An empirical analysis of the determinants of corporate investment decisions: Evidence from emerging market firms. Int. Res. J. Financ. Econ. 2009, 33, 134-141.

41. Vo, X.V. Leverage and corporate investment-Evidence from Vietnam. Financ. Res. Lett. 2019, $28,1-5$. [CrossRef]

42. Al-Afeef, M.A.; Al-Qudah, D.A.A. The Relationship between the Investment in Current Assets and Profitability \& Liquidity. J. Financ. Invest. Anal. 2015, 4, 11-22. [CrossRef]

43. Berle, A.A.; Means, G.C. The Modern Corporation and Private Property; The Macmillan Company: New York, NY, USA, 1933; Volume 81. [CrossRef]

44. Fama, E.F.; Jensen, M.C. Separation of Ownership and Control. J. Law Econ. 1983, 2, 301-325. [CrossRef]

45. Spitzeck, H.; Hansen, E.G. Stakeholder governance: How stakeholders influence corporate decision making. Corp. Gov. 2010, 10, 378-391. [CrossRef]

46. Uittenbogaard, R. Do Independent Boards Pay Higher Dividends? 2016. Available online: https://thesis.eur. nl/pub/37786/M223-Uittenboogaart_296586.pdf (accessed on 13 November 2018). 
47. Jensen, M.C. The Modern Industrial Revolution, Exit, and the Failure of Internal Control Systems. J. Financ. 1993, 48, 831-880. [CrossRef]

48. Grabowski, H.G.; Mueller, D.C. Managerial and Stockholder Welfare Models of Firm Expenditures. Rev. Econ. Stat. 1972, 54, 9. [CrossRef]

49. Aldrighi, D.M.; Kalatzis, A.E.G.; Pellicani, A. The Impact of Corporate Governance and Financial Constraints on Firms' Investment Decisions: Evidence from Brazil. SSRN Electron. J. 2012. [CrossRef]

50. Chung, K.H.; Wright, P.; Kedia, B. Corporate governance and market valuation of capital and RD investments. Rev. Financ. Econ. 2003, 12, 161-172. [CrossRef]

51. Gill, A.; Sharma, S.P.; Mand, H.S.; Mathur, N. The relationship between corporate governance and the investment decision of small business firms in India. J. Financ. Invest. Anal. 2012, 1, 41-59.

52. Yang, M.; Xiong, X. An Empirical Study of the Impact of Corporate Governance on RD Investment in High-Tech Enterprises. In Proceedings of the 2010 International Conference on Management and Service Science, MASS 2010, Wuhan, China, 24-26 August 2010. [CrossRef]

53. Huang, Y.S.; Wang, C.J. Corporate governance and risk-taking of Chinese firms: The role of board size. Int. Rev. Econ. Financ. 2015, 37, 96-113. [CrossRef]

54. Eklund, J.E.; Palmberg, J.; Wiberg, D. Ownership structure, board composition and investment performance. Corp. Ownersh. Control. 2009, 7, 120-130. [CrossRef]

55. Aktas, N.; Andreou, P.C.; Karasamani, I.; Philip, D. CEO Duality, Agency Costs, and Internal Capital Allocation Efficiency. Br. J. Manag. 2018, 30, 473-493. [CrossRef]

56. Mahadeo, J.D.; Soobaroyen, T.; Hanuman, V.O. Board Composition and Financial Performance: Uncovering the Effects of Diversity in an Emerging Economy. J. Bus. Ethics 2012, 105, 375-388. [CrossRef]

57. Mutlu, C.C.; Van Essen, M.; Peng, M.W.; Saleh, S.F.; Duran, P. Corporate Governance in China: A Meta-Analysis. J. Manag. Stud. 2018, 55, 943-979. [CrossRef]

58. Shukeri, S.N.; Shin, O.W.; Shaari, M.S. Does Board of Director's Characteristics Affect Firm Performance? Evidence from Malaysian Public Listed Companies. Int. Bus. Res. 2012, 5, 120. [CrossRef]

59. Cox, T.H.; Stacy, B. Managing cultural diversity: Implications for organizational competitiveness. Acad. Manag. Exec. 1991, 5, 45-56. [CrossRef]

60. Tsui, A.S.; Egan, T.D.; O’Reilly, C.A.I. Being Different: Relational Demography and Organizational Attachment. Adm. Sci. Q. 1992, 37, 549. [CrossRef]

61. Dutta, P.; Bose, S. Gender Diversity in the Boardroom and Financial Performance of Commercial Banks: Evidence from Bangladesh. Cost Manag. 2007, 34, 70-74. [CrossRef]

62. Francoeur, C.; Labelle, R.; Sinclair-Desgagne, B. Gender diversity in corporate governance and top management. J. Bus. Ethics 2008, 81, 83-95. [CrossRef]

63. Mirza, H.H.; Mahmood, S.; Andleeb, S.; Ramzan, F. Gender Diversity and Firm Performance: Evidence from Pakistan. J. Soc. Dev. Sci. 2012, 3, 161-166. [CrossRef]

64. Seierstad, C.; Gabaldon, P.; Mensi-Klarbach, H. Gender Diversity in the Boardroom: Volume 2: Multiple Approaches Beyond Quotas; Springer: Berlin/Heidelberg, Germany, 2017. [CrossRef]

65. Horwitz, S.K.; Horwitz, I.B. The Effects of Team Diversity on Team Outcomes: A Meta-Analytic Review of Team Demography; Sage Publications: Los Angeles, CA, USA, 30 December 2007. [CrossRef]

66. Sobral, F.; Bisseling, D. Exploring the black box in Brazilian work groups: A study of diversity, conflict and performance. BAR Braz. Adm. Rev. 2012, 9, 127-146. [CrossRef]

67. Ashforth, B.E.; Mael, F. Social Identity Theory and the Organization. Acad. Manag. Rev. 1989, 14, $20-39$. [CrossRef]

68. Jackson, S.E.; May, K.E.; Whitney, K. Understanding the Dynamics of Diversity in Decision Making Teams. Team Eff. Decis. Mak. Organ. 1995, 204, 261.

69. Loukil, N.; Yousfi, O. Does gender diversity on corporate boards increase risk-taking? Can. J. Adm. Sci. 2016, 33, 66-81. [CrossRef]

70. Cyert, R.M.; March, J.G. A Behavioral Theory of the Firm Second Edition. Business 1963, 32, 461. [CrossRef]

71. Altiner, S.; Ayhan, M.B. An approach for the determination and correlation of diversity and efficiency of software development teams. South Afr. J. Sci. 2018, 114, 1-9. [CrossRef]

72. Midavaine, J.; Dolfsma, W.; Aalbers, R. Board diversity and RD investment. Manag. Decis. 2016, 54, 558-569. [CrossRef] 
73. Masulis, R.W.; Wang, C.; Xie, F. Globalizing the boardroom-The effects of foreign directors on corporate governance and firm performance. J. Acc. Econ. 2012, 53, 527-554. [CrossRef]

74. Darmadi, S. Board Diversity and Firm Performance: The Indoesian Evidence. Corp. Ownersh. Control J. 2011, 8. [CrossRef]

75. Alabede, J.O. Effect of Board Diversity on Corporate Governance Structure and Operating Performance: Evidence from the UK Listed Firms. Asian J. Acc. Gov. 2016, 7, 67-80. [CrossRef]

76. Mahmood, C.K.; Malik, Q.A. Evaluation of Firm's Performance by Corporate Governance and Social Responsibility: A Moderating Role of Corporate Philanthropy. NUML Int. J. Bus. Manag. 2018, 13, 134-146.

77. Mirza, N.I.; Malik, Q.A. Effects of corporate governance on dividend decisions with a focus on moderating role of board diversity. Int. Trans. J. Eng. Manag. Appl. Sci. Technol. 2019, 10, 1-17.

78. Erhardt, N.L.; Werbel, J.D.; Shrader, C.B. Board of Director Diversity and Firm Financial Performance. Corp. Gov. 2003, 11, 102-111. [CrossRef]

79. Pindado, J.; De La Torre, C. The role of investment, financing and dividend decisions in explaining corporate ownership structure: Empirical evidence from Spain. Eur. Financ. Manag. 2006, 12, 661-687. [CrossRef]

80. Mansourinia, E.; Emamgholipour, M.; Rekabdarkolaei, E.A.; Hozoori, M. The effect of board size, board independence and CEO duality on dividend policy of companies: Evidence from Tehran stock exchange. Int. J. Econ. Manag. Soc. Sci. 2013, 2, 237-241.

Publisher's Note: MDPI stays neutral with regard to jurisdictional claims in published maps and institutional affiliations. 